\title{
Course Selection with AHP \& PROMETHEE Methods for Post Graduate Students: An Application in Kirikkale University Graduate School of Natural and Applied Sciences
}

\author{
Neşet Bedir ${ }^{1}$, Emir Hüseyin Özder2,a and Tamer Eren ${ }^{1}$ \\ ${ }^{1}$ Kirikkale University, Industrial Engineering Department, 71450 Kirikkale, Turkey \\ ${ }^{2}$ Baskent University, Management Information Systems Department, 06810 Ankara, Turkey
}

\begin{abstract}
Post Graduate Study has a very important role in people's career planning. Besides, it helps for gaining expertising on their fields. Specializing must be in the right area to reach their targets in line with people's interests. The aim of the study is to propose a model for students that determines which courses will be chosen on master course selection and this model gives an application example. In this study, course selection problem is discussed for post graduate students in Industrial Engineering Department of Kirikkale University. All criteria that are effected for selecting a course are identified by the help of survey then, significance levels are determined with using Analytical Hierarchy Process (AHP) which is a Multi-Criteria Decision Making Method. According to the weights which are determined before in AHP results, six classes weighted by PROMETHEE method in Industrial Engineering Department.
\end{abstract}

\section{Introduction}

Students always complain about not to acquaint with some information on selection of the elective courses throughout time in their post graduate education life. Necessary information cannot be given on time and in detail. Bottlenecks occur in the selection of elective courses. For this reason, some students cannot choose the classes they want [1]. Elective courses should respond to the demands of students in the way of diversity. Some arrangement would be made about courses that students want to take. Students must decide when choosing the course of considering multiple factors. For doing it right, there are various methods in the literature. Multi-Criteria Decision Making (MCDM) method is one of the technique located in literature as intuitive. Lots of MCDM methods are frequently encountered in the literature like; AHP, PROMETHEE, ELECTRE, DEMATEL, VIKOR and TOPSIS.

The aim of this study is to analyze the problems faced by students in course selection and to suggest a model for the integrated course selection. Post graduate courses selection problems are discussed of Kirikkale University Institute of Science and Technology Department of Industrial Engineering students. AHP and PROMETHEE methods were used as a solution method. Five factors, that influence the course selection, are weighted with AHP technique. Six courses are ordered with an alternative method PROMETHEE.
The outline of the paper are as follows: In the second section, importance of course selection problems has explained. In the third section, AHP and PROMETHEE methods are described which multi-criteria decisionmaking methods used in the solution of the problem. In the fourth chapter, the application made in Kirikkale University for course selection are described. The fifth and the last part, the results are given of the practices and some suggestions are made for future work.

\section{Course selection}

In post graduate education, students take elective compulsory courses on issues the requirements of the program and that take courses that related to their professional interests and personal skills for developing themselves. Students should know the features and benefits of the courses and they should select the appropriate course that suit for their skills.

\section{Multi-criteria decision making methods}

The optimization of several criteria at the same time makes complicate the decision-making process. In this case, the problem can be solved by applying MCDM. Multi-criteria decision-making methods are used in many fields. In this study, AHP and PROMETHEE multicriteria decision-making methods are used for the problem of the choosing of elective courses.

\footnotetext{
${ }^{\text {a }}$ Corresponding author: ehozder@baskent.edu.tr
} 


\subsection{Analytical Hierarchy Process (AHP) Method}

AHP method was developed by Thomas L. Saaty in 1980. Analytic Hierarchy Process; because the visualization of hierarchical basis to complex, multiperson and multi-criteria problems, to make this technique can be understood by managers. Selection process that uses quantitative and qualitative criteria, so the decision makers determine the relative importance of each criterion is based on the transmitter and then decide to choose between alternatives by each criterion [2]. The steps of the Analytic Hierarchy Process Many applications which form is listed below [3];

Step 1: Identification of the Problem: The identification of decision points and the decision-making problem occurs in the definition of the factors affecting them. The decision point is extremely important in terms of the consistency of the results to be defined clearly. The hierarchical structure of the identified problems are created at this stage. Located problems discussed at the beginning of the hierarchy. By affecting the intended destination of the problem it is written below. It is located in the lower part of the criteria comparison option to do.

Step 2: Creating a Pairwise Comparison Matrix:

At this stage, factor from comparison matrix is a square matrix of size. Matrix components on the diagonal of this matrix takes the value 1 . If the number of criteria is indicated as n, pairwise comparison square matrix will be $\mathrm{m} * \mathrm{n}$ dimension.

$$
\mathrm{A}=\left[\begin{array}{cccc}
a_{11} & a_{12} & \ldots & a_{1 n} \\
a_{11} & a_{22} & \ldots & a_{2 n} \\
\vdots & \vdots & \ldots & \vdots \\
a_{n 1} & a_{n 2} & \ldots & a_{n m}
\end{array}\right]
$$

Step 3: Determine the weight of the criteria

Decision matrix by weight is made to obtain normalized. Normalization process, each element the column vector $b$ is calculated by dividing the total column of each element in the matrix of pairwise comparisons. Equality is calculated by the Equation 2.

$$
b_{i j}=\frac{a_{i j}}{\sum_{i=1}^{n} a_{i j}}
$$

The resulting normalized matrix is formed as in Equation 3.

$$
\mathrm{C}=\left[\begin{array}{cccc}
c_{11} & c_{12} & \cdot & c_{1 n} \\
c_{21} & c_{22} & \cdot & c_{2 n} \\
: & : & : & : \\
c_{n 1} & c_{n 2} & \cdot & c_{n n}
\end{array}\right]
$$

Taking advantage of the $\mathrm{C}$ matrix by showing the distribution of the obtained percent value relative importance value to each other. As shown in Equation 4 using the arithmetic mean for each row to the priority vector $\mathrm{C}$ matrix in Equation 5, and $\mathrm{W}$ column vector is obtained.

$$
\begin{gathered}
w_{i}=\frac{\sum_{i=1}^{n} c_{i j}}{n} \\
W=\left[\begin{array}{c}
w_{1} \\
w_{2} \\
\cdot \\
w_{n}
\end{array}\right]
\end{gathered}
$$

Step 4: Calculation of Consistency Rate: Consistency Ratio (CR) calculation is based on the comparison of the the basic value and the number of factors $(\lambda) . \Lambda$ calculating the obtained first column vector $\mathrm{D}$. A vector is obtained as shown in Equation 6. and $\mathrm{W}$ multiplied by the weight vector.

$$
\mathrm{D}=\left[\begin{array}{cccc}
a_{11} & a_{12} & \cdot & a_{1 n} \\
a_{21} & a_{22} & \cdot & a_{2 n} \\
: & : & : & : \\
a_{n 1} & a_{n 2} & \cdot & a_{n n}
\end{array}\right] \times\left[\begin{array}{c}
w_{1} \\
w_{2} \\
\cdot \\
\cdot \\
w_{n}
\end{array}\right]
$$

Column D and W column vector corresponding elements of each part as a result of Equation 7 for each vector is obtained by using the basic $\mathrm{E}$ values.

$$
E_{i}=\frac{d_{i}}{w_{i}} \quad n i, \ldots, 2,1
$$

By dividing this number by the total value of $\lambda$ in Equation 8 is obtained.

$$
\lambda=\frac{\sum_{i=1}^{n} E_{i}}{n}
$$

After calculating $\lambda$ Consistency Index $(\mathrm{CI})$ is calculated with Equation 9.

$$
\mathrm{CI}=\frac{\lambda-\mathrm{n}}{n-1}
$$

In the last step; CI Random Index (RI) and named as indicated in Table 1 by dividing the standard correction value $\mathrm{C}$ is obtained in Equation 10.

$$
C R=\frac{C I}{R I}=\frac{\left(\lambda_{\max }-n /(n-1)\right)}{R I}
$$

Table 1. Randomness Index

\begin{tabular}{|c|c|c|c|c|c|c|c|}
\hline $\mathbf{n}$ & $\mathbf{1}$ & $\mathbf{2}$ & $\mathbf{3}$ & $\mathbf{4}$ & $\mathbf{5}$ & $\mathbf{6}$ & $\mathbf{7}$ \\
\hline R.I. & 0 & 0 & 0,58 & 0,9 & 1,12 & 1,24 & 1,32 \\
\hline $\mathbf{n}$ & $\mathbf{7}$ & $\mathbf{9}$ & $\mathbf{1 0}$ & $\mathbf{1 1}$ & $\mathbf{1 2}$ & $\mathbf{1 3}$ & $\mathbf{1 4}$ \\
\hline R.I. & 1,14 & 1,45 & 1,49 & 1,51 & 1,48 & 1,56 & 1,57 \\
\hline
\end{tabular}

\subsection{PROMETHEE Method}

PROMETHEE is developed by Brans [4] as a multidecision procedure. Decision point determines the main stage of order with PROMETHEE I (partial order) and PROMETHEE II (full sequence) Methods. Promethean method is based on binary comparison of the decision point by the evaluation factors. But the main difference from other multiple decision-making process, In addition to the weight of the evaluation factors indicating the level 
of importance of the relationship between them is that each evaluation factor to consider its own internal affair. PROMETHEE method, compared to other multi-criteria decision-making methods in terms of scope of application and can be adapted to a number of criteria that can be expressed with the actual values is a simple method. PROMETHEE method consists of 7 steps [5]:

Step 1: Creating the Data Matrix: $w=(w 1, w 2, \ldots, w k) k$ by $\mathrm{c}$ with weight $=(\mathrm{f} 1, \mathrm{f} 2, \ldots, \mathrm{fk})$ to the alternative being considered by $=(a, b, c, \ldots)$ for data matrixIt is created as shown in Table 2.

Table 2. Data Matrix

\begin{tabular}{|c|c|c|c|c|c|c|}
\hline \multicolumn{2}{|c|}{} & \multicolumn{5}{|c|}{ Evaluation Factors } \\
\cline { 3 - 7 } & $f_{1}$ & $f_{2}$ & $f_{3}$ & $\cdots$ & $f_{k}$ \\
\hline \multirow{4}{*}{$\begin{array}{c}\text { Decision } \\
\text { Points }\end{array}$} & $\mathrm{A}$ & $f_{1}(\mathrm{~A})$ & $f_{2}(\mathrm{~A})$ & $f_{3}(\mathrm{~A})$ & $\cdots$ & $f_{k}(\mathrm{~A})$ \\
\cline { 2 - 7 } & $\mathrm{B}$ & $f_{1}(\mathrm{~B})$ & $f_{2}(\mathrm{~B})$ & $f_{3}(\mathrm{~B})$ & $\cdots$ & $f_{k}(\mathrm{~B})$ \\
\cline { 2 - 7 } & $\mathrm{C}$ & $f_{1}(\mathrm{C})$ & $f_{2}(\mathrm{C})$ & $f_{3}(\mathrm{C})$ & $\cdots$ & $f_{k}(\mathrm{C})$ \\
\cline { 2 - 7 } & $\cdots$ & $\cdots$ & $\cdots$ & $\cdots$ & $\cdots$ & $\cdots$ \\
\hline Weights & $w_{i}$ & $w_{1}$ & $w_{2}$ & $w_{3}$ & $\cdots$ & $w_{k}$ \\
\hline
\end{tabular}

Step 2: Identification of preferred function Criteria: Six different preference function is used for implementation.

Table 3. Preference Functions

\begin{tabular}{|c|c|c|c|c|}
\hline Type & Parameters & & & Graph, $p(x)$ \\
\hline $\begin{array}{l}\text { Type-I } \\
\text { (usual) }\end{array}$ & - & $p(x)= \begin{cases}0, & \forall x \leq \\
1, & \forall x \geq\end{cases}$ & & 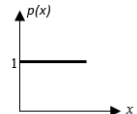 \\
\hline $\begin{array}{l}\text { Type-II } \\
\text { (U-type) }\end{array}$ & $l$ & $p(x)= \begin{cases}0, & x \leq \\
1, & x \geq\end{cases}$ & & \\
\hline $\begin{array}{l}\text { Type-III } \\
\text { (V-type) }\end{array}$ & $m$ & $p(x)= \begin{cases}x / m, & x= \\
1, & x=\end{cases}$ & & $\AA^{p(x)}$ \\
\hline $\begin{array}{l}\text { Type-IV } \\
\text { (level) }\end{array}$ & $g . p$ & $p(x)= \begin{cases}0, & \\
1 & \\
\frac{2}{2}, & \\
1, & q\end{cases}$ & $\begin{array}{r}x \leq q \\
\leq q+p \\
>s+r\end{array}$ & \\
\hline $\begin{array}{l}\text { Type-V } \\
\text { (Linear) }\end{array}$ & s.r & $p(x)=\left\{\begin{array}{c}0, \\
(x-s) / r . \\
1,\end{array}\right.$ & $\begin{array}{c}x \leq s \\
s<x \leq s+r \\
x>s+r\end{array}$ & \\
\hline
\end{tabular}

Step 3: Determination of Preference Function: Preferred alternative identified for common functions are shown in Figure $1 \mathrm{a}$ and $\mathrm{b}$ common preference for alternative function equation (11) is created.

$$
\mathrm{P}(\mathrm{a}, \mathrm{b})=\left\{\begin{array}{ll}
0 & , f(a) \leq f(b) \\
p[f(a)-f(b)] & , f(a)>f(b)
\end{array}\right\}
$$

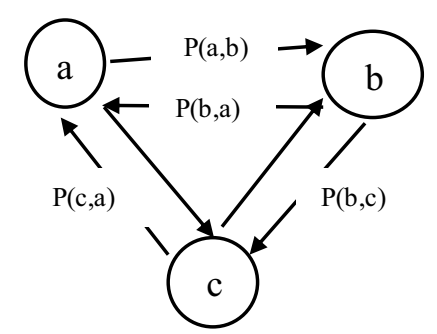

Figure 1. Schematic representation of the common preference function

Step 4: Determine the preferred index: the choice of the Common functions can be determined preference index for each pair of alternatives.

$\mathrm{W}(\mathrm{i}=1,2, \ldots \mathrm{k})$ evaluated by weight by having a $\mathrm{k}$ and $\mathrm{b}$ the alternative preferred index are calculated by Equation 12 .

$$
\pi(\mathrm{a}, \mathrm{b})=\frac{\sum_{i=1}^{k} w_{i}^{*} P_{i}(a, b)}{\sum_{i=1}^{k} w_{i}}
$$

Step 5: Positive $\left(\boldsymbol{\Phi}^{+}\right)$and Negative $\left(\boldsymbol{\Phi}^{-}\right)$Superiority Alternative rule for determining: Alternatives are calculated with (13) and (14).

$$
\begin{aligned}
& \Phi^{+}(a)=\frac{1}{n-1} \sum \pi(a, b) \\
& \Phi^{-}(a)=\frac{1}{n-1} \sum \pi(b, a)
\end{aligned}
$$

Step 6: Determination of PROMETHEE I Partial Priority for Alternatives: In some cases are involved in the determination of the two alternatives $\mathrm{A}$ and $\mathrm{B}$ for partial priority.

Situation I: Equation 15, 16, 17 If either of the conditions, a preferable alternative to the alternative $b$.

$$
\begin{aligned}
& \Phi^{+}(\mathrm{a})>\Phi^{+}(\mathrm{b}) \text { and } \Phi^{-}(\mathrm{a})<\Phi^{-}(\mathrm{b}) \\
& \Phi^{+}(\mathrm{a})>\Phi^{+}(\mathrm{b}) \text { and } \Phi^{-}(\mathrm{a})=\Phi^{-}(\mathrm{b}) \\
& \Phi^{+}(\mathrm{a})=\Phi^{+}(\mathrm{b}) \text { and } \Phi^{-}(\mathrm{a})<\Phi^{-}(\mathrm{b})
\end{aligned}
$$

Situation II: If the condition does not allow the following, $\mathrm{A}$ and $\mathrm{B}$ alternative is identical.

$$
\Phi^{+}(\mathrm{a})=\Phi^{+}(\mathrm{b}) \text { and } \Phi^{-}(\mathrm{a})=\Phi^{-}(\mathrm{b})
$$

Situation III: If either of the following conditions A alternative, comparable to the B alternative.

$$
\begin{aligned}
& \Phi^{+}(\mathrm{a})>\Phi^{+}(\mathrm{b}) \text { and } \Phi^{-}(\mathrm{a})>\Phi^{-}(\mathrm{b}) \\
& \Phi^{+}(\mathrm{a})<\Phi^{+}(\mathrm{b}) \text { and } \Phi^{-}(\mathrm{a})<\Phi^{-}(\mathrm{b})
\end{aligned}
$$

Step 7: PROMETHEE II complete with identification of priorities for alternatives: The following equation is calculated with the help of exactly the priorities for each alternative. Calculated values of all alternatives with full priority ranking is determined by assessing precisely the same plane.

$$
\Phi(\mathrm{a})=\Phi^{+}(\mathrm{a})-\Phi^{-}(\mathrm{a})
$$


Depending on the exact priority value calculated for A and $\mathrm{B}$ are two alternative decisions are given below. If $\Phi(\mathrm{a})>\Phi(\mathrm{b})$, A Alternative is superior. If $\Phi(\mathrm{a})=\Phi(\mathrm{b})$, A and B are identical alternatives.

\section{Literature review}

In this section, studies in the literature regarding course selection were examined.

Woolnough [6] measured the factors of selecting the elective courses of freshmen who are studying biology by applying survey in his study. Results show that women are less interested in science than men.

Bewick and Southern, [7] were intended to determine the cause of gender trends arising from the difference between the students who choose mathematics by using survey on 198 students. Among the reasons for choosing math students indicated that they have significant differences due to gender.

Isobel [8] examined the factors that influence students' choice of university. The author used the questionnaire for identifying the factors of decision process of the students.

Hodgkinson and Innes [9] studied the effect of environmental factors of course selection on freshmen who are studying in different departments at the same university.

Dündar [10] investigated the problem selection of elective courses on business students. Some of criteria are verified like Skills of the instructor, course name and content, information gathered by students and those criteria's priority is specified by AHP Method.

Tezcan ve Gümüş [11] tried to find factors of choosing an elective course from the perspective of students. And also they tried to find the selection order of priority.

Salomon et al. [12] have studied in Brazil and used the AHP for the selection of instructor for a faculty.

Aydin et al. [13] aims to select the best location for a new hospital which have planned to open in Ankara., it has been determined the most appropriate site selection by taking the opinion of experts to implement the project using AHP technique.

Kutlu et al. [14] studied course selection problem in Kirikkale University Industrial Engineering for 3. and 4. grade students. They used AHP and TOPSIS Method as Multi-Criteria Decision Making Methods. The weights of the factors affecting the selection of courses are calculated with AHP, the courses are sequencing with TOPSIS Method.

Bansal and Kumar [15], Bedir and Eren [16], Bedir et al. [17] and Kazan et al. [18] are used AHP and PROMETHEE methods in their studies together for doing selection.

\section{Case study}

Our problem is choosing the most appropriate elective course for graduate students within certain criteria. Steps are shown in Figure 2.

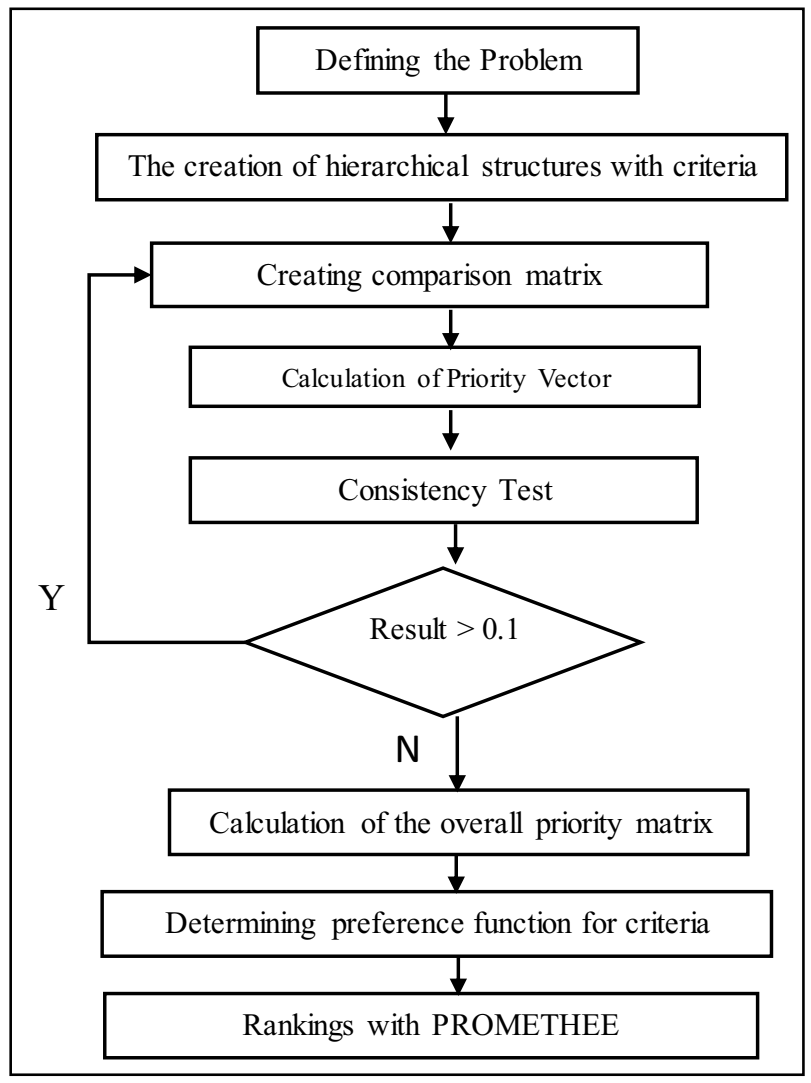

Figure 2. Application Steps

\subsection{Defining the Problem}

Our problem is choosing the most appropriate course in accordance with certain criteria of graduate students in Kirikkale University Industrial Engineering Department.

Elective Courses for Graduate Students:

-Integer Modelling and Optimization

-Sequencing and Scheduling

- Simulation Languages

-Artificial Intelligence and Expert Systems

-Intelligent Business Systems

-Stochastic Processes

Determination of criteria that influence the choice of the course:

In determining the effective factors in the selection of courses in industrial engineering department results of a survey administered to students who are studying it is determined as follows.

- Content of the Course

-Day of Course

-Interests of Students

-Instructor's Attitude

-Academic Expectations

\subsection{Solution of the Problem}

Determination of Criteria Weight with AHP 
Step 1: Creating a hierarchical structure: In the light of gathering data results, hierarchical structure is getting shaped and shown in Figure 3.

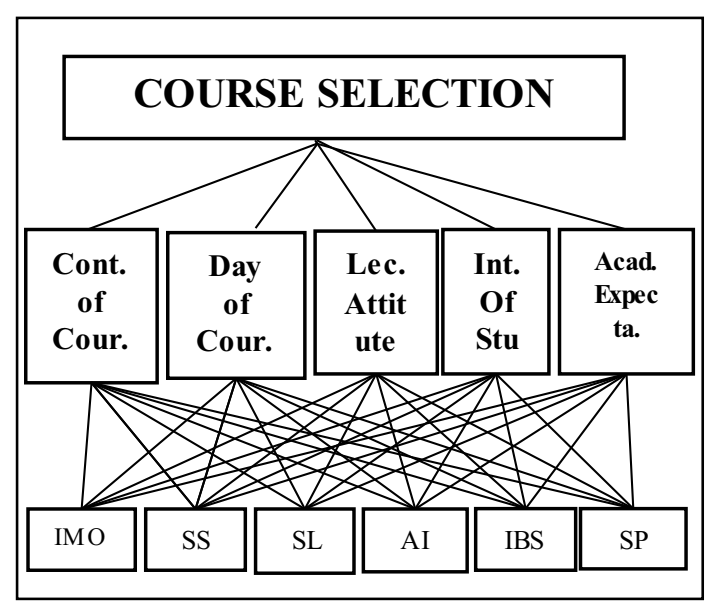

Figure 3. Hierarchical Structure

Step 2: Determination of Priority: The hierarchical structure created after the scale is determined by the criteria for comparison. Unlike other multi-criteria decision-making methods, in the AHP, Satty [19] is used 1-9 scale by the gain on the literature which is shown in Table 4.

Table 4. Saaty's Scala of 1 - 9

\begin{tabular}{|c|c|c|}
\hline $\begin{array}{l}\text { Intensity of } \\
\text { Importance }\end{array}$ & Definition & Explanation \\
\hline 1 & $\begin{array}{c}\text { Equal } \\
\text { Importance }\end{array}$ & $\begin{array}{l}\text { Two activities contribute equally to } \\
\text { the objective }\end{array}$ \\
\hline 3 & $\begin{array}{l}\text { Moderate } \\
\text { importance }\end{array}$ & $\begin{array}{l}\text { Experience and judgement slightly } \\
\text { favour one activity over another }\end{array}$ \\
\hline 5 & $\begin{array}{l}\text { Strong } \\
\text { importance }\end{array}$ & $\begin{array}{l}\text { Experience and judgement strongly } \\
\text { favour one activity over another }\end{array}$ \\
\hline 7 & $\begin{array}{c}\text { Very strong } \\
\text { or } \\
\text { demonstrated } \\
\text { importance }\end{array}$ & $\begin{array}{c}\text { An activity is favoured very } \\
\text { strongly over another; its } \\
\text { dominance demonstrated in practice }\end{array}$ \\
\hline 9 & $\begin{array}{l}\text { Extreme } \\
\text { importance }\end{array}$ & $\begin{array}{c}\text { The evidence favouring one activity } \\
\text { over another is of the highest } \\
\text { possible order of affirmation }\end{array}$ \\
\hline $2,4,6,8$ & $\begin{array}{c}\text { Average } \\
\text { (compromise) } \\
\text { values }\end{array}$ & $\begin{array}{l}\text { Reconciliation between two } \\
\text { consecutive values to be used in } \\
\text { court if necessary }\end{array}$ \\
\hline
\end{tabular}

Step 3: Bilateral Comparison Matrix and Solution: The geometric mean of the answers given by the students to create the pairwise comparison matrix on Table $\mathrm{x}$ below were created according to the factors like Content of the Course, Day of Course, Interests of Students and Instructor's Attitude.

Table 5. Pairwise Comparison Matrix

\begin{tabular}{|c|c|c|c|c|c|}
\hline Criteria & CC & DL & IS & LA & AE \\
\hline CC & 1,000 & 3,000 & 1,000 & 4,000 & 1,000 \\
\hline DL & 0,333 & 1,000 & 0,333 & 0,500 & 0,500 \\
\hline
\end{tabular}

\begin{tabular}{|c|c|c|c|c|c|} 
IS & 1,000 & 3,000 & 1,000 & 2,000 & 1,000 \\
\hline LA & 0,250 & 2,000 & 0,500 & 1,000 & 2,000 \\
\hline AE & 1,000 & 3,000 & 1,000 & 3,000 & 1,000 \\
\hline
\end{tabular}

Step 4: Normalization and Relative Importance Weights: Pairwise comparison matrix forming in the previous step will be normalized. The relative importance weights by averaging each row in the resulting matrix is obtained Table 6.

Table 6. Relative Importance Weights with Criteria

\begin{tabular}{|c|c|}
\hline Criteria & Weights \\
\hline CC & 0,295 \\
\hline DL & 0,078 \\
\hline IS & 0,245 \\
\hline LA & 0,173 \\
\hline AE & 0,208 \\
\hline
\end{tabular}

Step 5: Calculation of Ratio Consistency: Consistency of actions taken in this step is tested. Consistency is calculated by this formulation:

$$
C R=\frac{C I}{R I}=\frac{\left(\lambda_{\max }-n /(n-1)\right)}{R I}
$$

Randomness index are shown in Table 7.

Table 7. Randomness Index

\begin{tabular}{|c|c|c|c|c|c|c|c|}
\hline $\mathbf{n}$ & $\mathbf{1}$ & $\mathbf{2}$ & $\mathbf{3}$ & $\mathbf{4}$ & $\mathbf{5}$ & $\mathbf{6}$ & $\mathbf{7}$ \\
\hline R.I. & 0 & 0 & 0,58 & 0,9 & 1,12 & 1,24 & 1,32 \\
\hline $\mathbf{n}$ & $\mathbf{7}$ & $\mathbf{9}$ & $\mathbf{1 0}$ & $\mathbf{1 1}$ & $\mathbf{1 2}$ & $\mathbf{1 3}$ & $\mathbf{1 4}$ \\
\hline R.I. & 1,14 & 1,45 & 1,49 & 1,51 & 1,48 & 1,56 & 1,57 \\
\hline & $\mathrm{CI}=\frac{5,396-5}{5-1}=0,099$ \\
$\mathrm{RI}=1,12(\mathrm{n}=5)$ & \\
$\mathrm{CR}=\frac{0,099}{1,12}=0,088<0,10$
\end{tabular}

Our result is consistent.

Step 6: Final Determination of the sequence: In this step PROMETHEE method using the weights obtained by the AHP was applied in ranking the alternatives.

Sorting the Courses with PROMETHEE

The second survey is applied to the Graduate students and obtained data are shown in Table 8 .

Table 8. Data Matrix

\begin{tabular}{|c|c|c|c|c|c|c|}
\hline & Candidate & \multicolumn{6}{|c|}{ Evaluation Factors } \\
\cline { 3 - 8 } & No & CC & DL & LA & IS & AE \\
\hline \multirow{4}{*}{$\begin{array}{c}\text { Decision } \\
\text { Points }\end{array}$} & D1 & 3 & 2 & 5 & 3 & 4 \\
\cline { 2 - 8 } & D2 & 4 & 3 & 4 & 4 & 5 \\
\cline { 2 - 8 } & D3 & 4 & 3 & 5 & 5 & 5 \\
\cline { 2 - 8 } & D4 & 3 & 4 & 4 & 5 & 4 \\
\cline { 2 - 8 } & D5 & 5 & 3 & 4 & 5 & 4 \\
\cline { 2 - 8 } & D6 & 4 & 3 & 5 & 4 & 3 \\
\hline
\end{tabular}




\begin{tabular}{|l|l|l|l|l|l|l|}
\hline Weights & $w_{i}$ & 0,295 & 0,078 & 0,245 & 0,173 & 0,208 \\
\hline
\end{tabular}

After the data matrix is done, preference functions is verified by Brans [20] who created specifically for PROMETHEE Method. This functions are shown in Figure 3. For Quantitative criteria; third or fifth type (linear) preference functions are used and for qualitative data first (ordinary) type or fourth (level) preferred type functions are used [21]. Visual PROMETHEE program is used to sort with the help of PROMETHEE Method. A data input program used is shown in Figure 4.

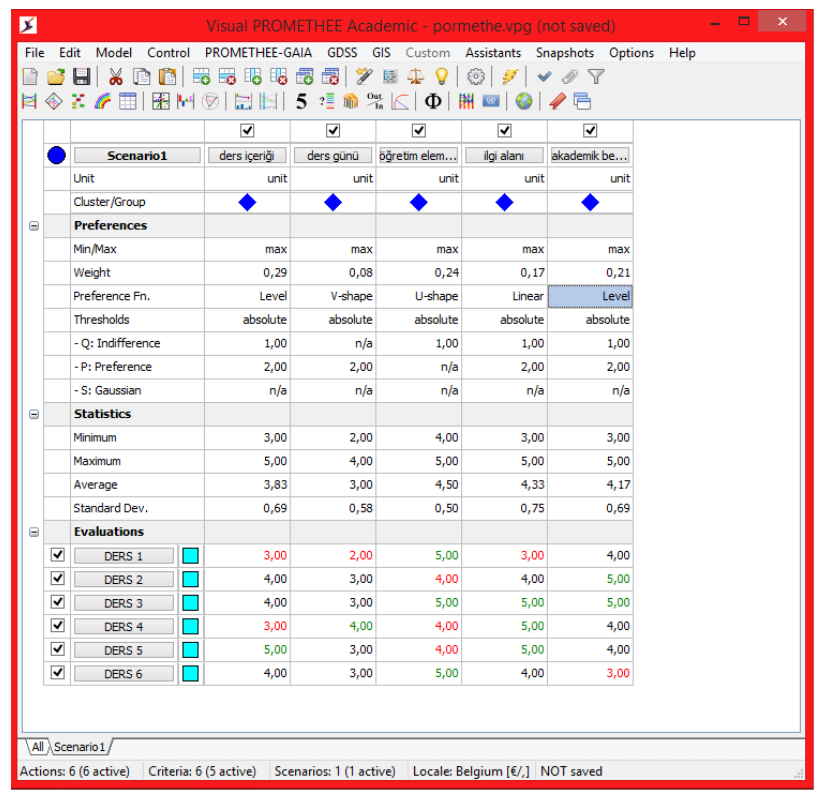

Figure 4. Program Data Input

After the obtained data are verified as input, the program output is shown in Figure 5.

\begin{tabular}{|c|c|c|c|c|c|}
\hline E & & ETH & Flow Ta & - & $x$ \\
\hline Rank & & & Phi & Phì & Phi- \\
\hline 1 & DERS 5 & $\square$ & 0,1528 & 0,1606 & 0,0078 \\
\hline 2 & DERS 3 & $\square$ & 0,0763 & 0,0841 & 0,0078 \\
\hline 3 & DERS 2 & $\square$ & 0,0416 & 0,0494 & 0,0078 \\
\hline 4 & DERS 4 & $\square$ & 0,0224 & 0,0815 & 0,0591 \\
\hline 5 & DERS 6 & $\square$ & $-0,0833$ & 0,0078 & 0,0911 \\
\hline 6 & DERS 1 & $\square$ & $-0,2098$ & 0,0000 & 0,2098 \\
\hline
\end{tabular}

Figure 5. Program Result

\section{Results}

Today, the management processes become more complex and lots of factors that influence the decision-making processes. People are forced to make a choice from using different technologies, systems, policies and strategies to find solutions for the problems. The excess of the criteria to be considered in deciding complicates the decision problem. At this point, use of multi-criteria decisionmaking methods are extremely important in terms of consistency of the results. In this study, course selection is discussed problems of graduate students with using a multi-criteria decision making method as AHP and PROMETHEE methods in Kirikkale University, Institute of Science and Technology Department of Industrial Engineering. Criteria which are affecting students in course selection are determined with a survey applied to the students. The resulting criteria are weighted with AHP. Given the weight obtained by the AHP was sequenced with courses PROMETHEE method. In future studies, new criteria may be added and consulted other multi-criteria decision-making methods can be used in.

\section{References}

1. A. Demir, Üniversitedeki Seçmeli Ders Uygulamasının Ögrenciler ve Ögretim Üyelerince Değerlendirilmesi, PDRD, 27 (1996).

2. Z. Anık, Nesne Yönelimli Yazılım Dillerinin Analitik Hiyerarşi ve Analitik Network Prosesi ile Karşılaştırılması ve Değerlendirilmesi, GÜ, (2007).

3. T. L. Saaty, Decision making with the analytic hierarchy process. Int. JSS, 11 (2008).

4. J. P. Brans, P. H. Vincke, A preference ranking organization method: The PROMETHEE method, MS, 31 647-656 (1982).

5. M. Dağdeviren, \& E. Eraslan, Promethee Siralama Yöntemi ile Tedarikçi Seçimi, GÜMMF, 23 69-75. (2008).

6. B. E. Woolnough, Why Students Choose Physics, or Reject It. Physics Education, 29 368-374 (1994).

7. V. Bewick, \& J. Southern, Factors Influencing Students' Choice of Mathematics at A-Level. TMIA 16 74- 78 (1997).

8. F. R. Isobel, Influences on Choice of Course Made by University. Year 1 Bioscience Students a Case Study. IJSE, 22, 1201-1218. (2000).

9. S. P. Hodgkinson, \& J. M. Innes, The Attitudinal Influence of Career Orientation in 1 st-Year University Students: Environmental Attitudes as a Function of Degree Choice. JEE, 32, 37-40. (2001).

10. S. Dündar, Ders Seçiminde Analitik Hiyerarşi Proses Uygulaması. SDUJFE \& AS, 13 (2008).

11. H. Tezcan, \& Y. Gümüş, Üniversite Öğrencilerinin Seçmeli Ders Tercihlerine Etki Eden Faktörlerin Araştırılması. GEFD, 28 1-17 (2008).

12. V. A. Salomon, F. S. Duarte, J. L. Junior, \& N. Paula, Faculty selection for a Brazilian private higher education institution. In International Symposium on the Analytic Hierarchy Process, 1 (2009).

13. Ö. Aydin, S. Öznehir, E. Akcali, Ankara İçin Optimal Hastane Yeri Seçiminin Analitik Hiyerarşi Süreci Ile Modellenmesi. SDÜİ ve İBFD, 14 69-86 (2009). 
14. B. S. Kutlu, Y. A. Abalı, T. Eren, Çok Ölçütlü Karar Verme Yöntemleri İle Seçmeli Ders Seçimi. KÜSBD, 2 5-25 (2012).

15. A. Bansal, P. Kumar, 3PL selection using hybrid model of AHP-PROMETHEE, IJS \& OM, 14 373397 (2013).

16. N. Bedir, T. Eren, AHP-PROMETHEE Yöntemleri Entegrasyonu Ile Personel Seçim Problemi: Perakende Sektöründe Bir Uygulama, 16. Uluslararası Ekonometri, Yöneylem Araştırması Ve İstatistik Sempozyumu, 16 (2015).

17. N. Bedir, E. H. Özder, T. Eren, The Third Party Logistics Firm Selection Using AHP-PROMETHEE Methods. 13th International Logistics and Supply Chain Congress: 13 (2015).

18. H. Kazan, S. Özçelik, \& E. H. Hobikoğlu, Election of Deputy Candidates for Nomination with AHPPromethee Methods. P-SBS, 195 603-613 (2015).

19. T. L. Saaty, How to Make a Decision : The Analytic Hierarchy Process, Interfaces, 619 - 43 (1994),

20. J. P. Brans, P. H. Vincke, B. Mareschall, How to select and how to rank projects: The PROMETHEE method, EJOR, 14 228-238 (1986).

21. R. S. Bhatti, P. Kumar, \& D. Kumar, A Fuzzy AHP model for $3 P L$ selection in Lead Logistics Provider scenarios. EIS \& IIICI, 1 261-277 (2010). 